\title{
Experimental Evaluation of Solids Suspension in Canyon Process Vessels (U)
}

by

N. M. Hassas

* Westinghouse Savannah River Company

Savannah River Site

Aiken, South Carolina 29808

DOE Contract No. DE-AC09-89SR18035

This paper was prepared in connection with work done under the above contract number with the U.S. Department of Energy. By acceptance of this paper, the publisher and/or recipient acknowledges the U. S. Government's right to retain a nonexclusive, royalty-free license in and to any copyright covering this paper, along with the right to reproduce and to authorize others to reproduce all or part of the copyrighted paper.

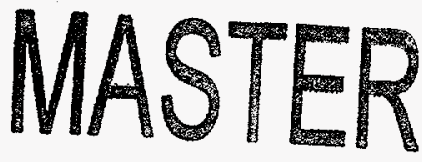




\section{DISCLAIMER}

Portions of this document may be illegible in electronic image products. Images are produced from the best available original document. 


Keywords: Uniformity
Canyon vessels
Solids suspension
Mixing

Retention: Permanent

Classification: $\mathrm{U}$

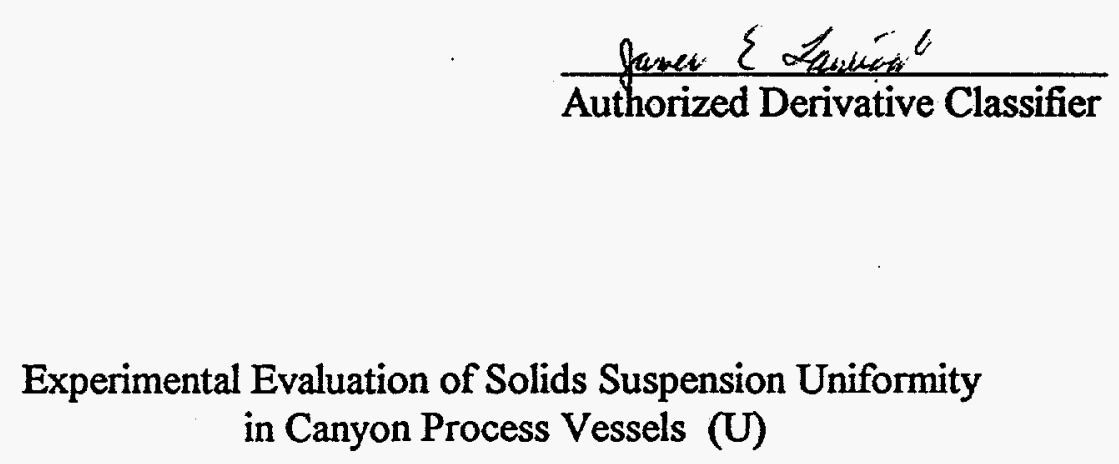

N. M. Hassan

June 25, 1996

\section{Patent Status}

This internal management report is being transmitted without DOE patent clearance, and no further dissemination or publication shall be made of the report without prior approval of the DOE patent counsel. 
Chemical Process Technology Department

Chemical \& HydrogenTechnology Section

WSRC-TR-96-0148

Revision 0

\section{DISCLAIMER}

This report was prepared as an account of work sponsored by an agency of the United States Government. Neither the United States Government nor any agency thereof, nor any of their employees, makes any warranty, express or implied, or assumes any legal liability or responsibility for the accuracy, completeness, or usefulness of any information, apparatus, product, or process disclosed, or represents that its use would not infringe privately owned rights. Reference herein to any specific commercial product, process, or service by trade name, trademark, manufacturer, or otherwise does not necessarily constitute or imply its endorsement, recommendation, or favoring by the United States Government or any agency thereof. The views and opinions of authors expressed herein do not necessarily state or reflect those of the United States Government or any agency thereof.

This report has been reproduced directly from the best available copy.

Available to DOE and DOE contractors from the Office of Scientific and Technical Information, P.O. Box 62, Oak Ridge, TN 37831; prices available from (615) 576-8401.

Available to the public from the National Technical Information Service, U.S. Department of Commerce, 5285 Port Royal Road, Springfield, VA 22161. 
N. M. Hassan

Issued: June 25, 1996

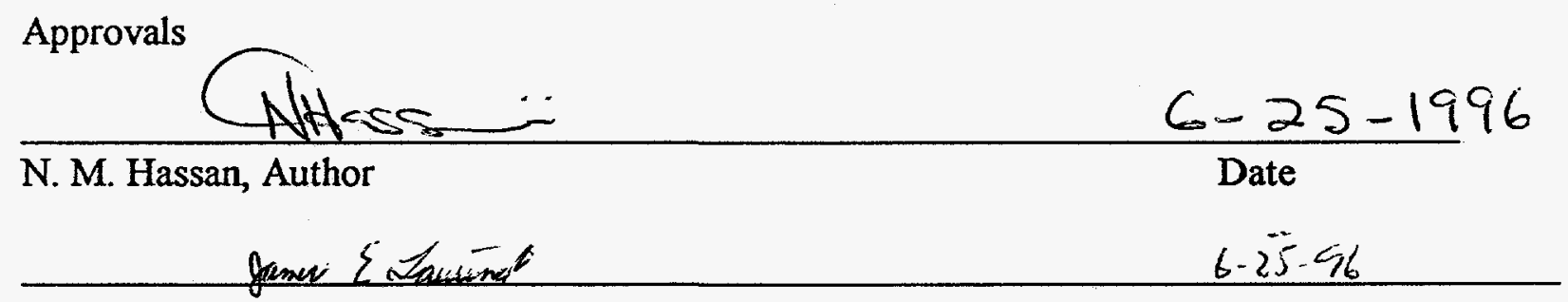

J. E. Laurinat, Technical Reviewer

Date 
Chemical Process Technology Department

Chemical \& HydrogenTechnology Section

WSRC-TR-96-0148

Revision 0

\section{Table of Contents}

Section

Page

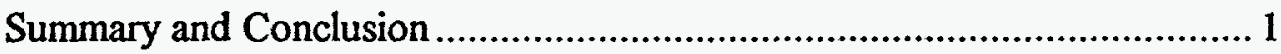

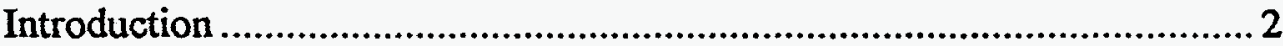

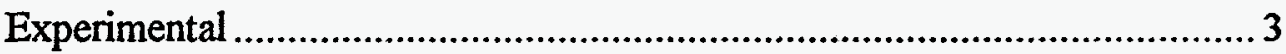

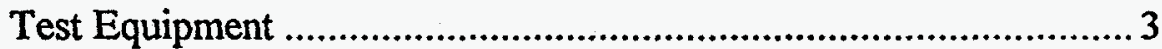

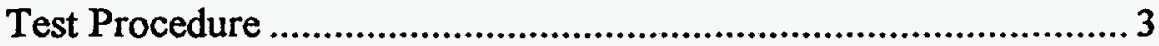

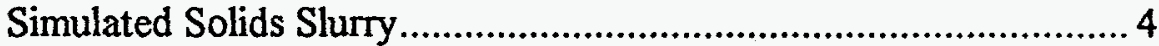

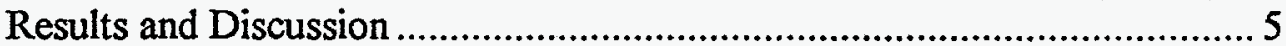

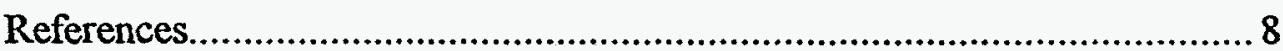

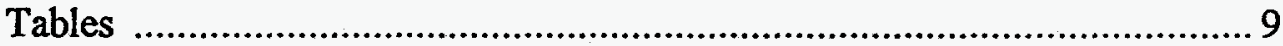

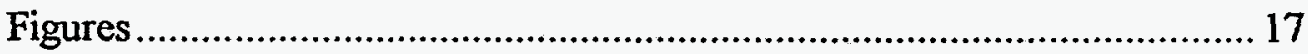




\title{
Experimental Evaluation of Solids Suspension Uniformity in Canyon Process Vessels (U)
}

\author{
N. M. Hassan \\ Westinghouse Savannah River Company \\ Savannah River Site \\ Aiken, SC 29808
}

\section{SUMMARY AND CONCLUSION}

Experimental evaluation of solids suspension in canyon process vessels was performed at several paddle agitator speeds and different volume levels in a geometrically similar vessel. The paddle agitator speeds examined were $280,370,528$, and $686 \mathrm{rpm}$ and volume levels were $30 \%, 50 \%$, and $70 \%$ fill capacity. Experiments were conducted with simulated solid particles that have particle size range and density similar to plutonium particles and corrosion products typically seen in canyon vessels. Solids suspension took place in baffled cylindrical vessel equipped with two flat-blade agitators and cooling helices.

The data collected from model equipment were analyzed for nickel content to simulate plutonium particles seen in canyon vessels. The analytical results were employed to determine the degree of suspension of nickel in slurry. Experimental results indicate that, at a minimum agitator speed of $280 \mathrm{rpm}$, up to $95 \%$ suspension was achieved for nickel particles. Scale-up of model tests using an equal power per unit volume relationship between the model and plant equipment show that a plant agitator speed of $68 \mathrm{rpm}$ provides nearly complete uniformity of suspension of solids in canyon vessels. The results also indicate that the degree of suspension of solid particles decreases with increasing volume levels, as expected. The data collected from vertical sampling heights directly above the regular sampling location revealed no apparent difference in the degree of 
Chemical Process technology Department

Chemical \& Hydrogen Technology Section
WSRC-TR-96-0148

Revision 0

suspension of solid particles in the axial direction. Therefore, it is concluded that current agitator speed in process vessels (i.e. $68 \mathrm{rpm}$ ) is sufficient to provide nearly complete uniformity of plutonium particles in canyon vessels.

\section{INTRODUCTION:}

A previous study performed to document the quality of solids suspension in canyon process vessels, WSRC-TR-95-0258, "Mixing Quality Characterization in Separations Process Tanks Part II: Solid-Liquid Suspension (U) ", suggested a 1.7-fold increase of the plant agitator speed to at least $120 \mathrm{rpm}$ for the attainable condition of complete, but non-uniform, suspension of solids in separations process vessels. The study, which was conducted with simulated material (sea sand), identified appropriate total liquid levels, minimum agitation speed for off the bottom suspension for two geometrically similar scales of operation, and the conditions under which the regular plant sampling point gives results comparable to the average of variously placed measurements around the vessel. Since the simulated material that was previously used (sand) had larger particle size range and smaller average density than heaviest particles (Plutonium particles) found in canyon vessels, further experimental work was needed to be conducted with simulated solids (surrogate) in slurry that had physical properties (e.g. average density and particle size range) similar to the solids found in canyon vessels.

This series of experiments was aimed at evaluating the performance of current agitation in canyon process vessels to provide nearly complete uniformity of solid particles in suspension. The experiments were conducted in model equipment to determine the agitator speed that would provide complete off-bottom suspension and/or nearly complete uniformity of solid particles with average density and particle size range similar to that of solids typically seen in canyon vessels. Near complete uniformity is defined hereafter as the degree of suspension in which the ratio of the weight percentage of solids in suspension to the weight percentage of solids in the agitated vessel is up to $95 \%$ and nearly equal at all 
points in the vessel. Complete uniformity, which is defined as $100 \%$ suspended solids, can only be approached but never really achieved in practice.

An important variable in assessing the degree of suspension of solid particles is the settling velocity of particles being suspended, which is a function of particle size and density. Sine plutonium particles typically seen in canyon vessels have average settling velocity of less than $0.5 \mathrm{ft} / \mathrm{min}$ in the Stokes Law region (Table 2), they settle so slowly that they are relatively easy to disperse and complete uniformity is relatively easy to obtain. In the presence of corrosion products and silica, however, the solids may only be lifted off the bottom by a slow moving paddle agitator and not uniformly suspended. Thus, experiments were conducted at several different volume levels and paddle agitator speeds, including one which reflects the normal canyon operation, to determine the agitator speed for complete suspension of solid particles with appropriate size and average density relative to solids in canyon vessels.

\section{EXPERIMENTAL}

Test Equipment: The details of the model equipment was given in WSRC-TR-0258, "Mixing Quality Characterization in Separations Process Tanks, Part II: Solids Suspension". It consists of a cylindrical, flat-bottom, Plexiglas tank with an inside diameter of 18 inches and an overall height of 36 inches. The tank is equipped with six radial baffles of width equal 1.25 inches, three banks of coil helices made of $1 / 2$-inch diameter stainless steel tubing, and two shear-type radial flow, four-bladed paddle agitators. The flat blades were 4.5-inch diameter and were mounted on a centrally located shaft. All of the model equipment dimensions (Table I) were chosen such that the ratio of the length scale of the plant equipment to lab equipment was 5.33:1.

Test Procedure: Known amounts of simulated solids in slurry with density and particle sizes similar to solids in canyon vessels were charged to the model vessel. The volume level was adjusted to the desired fill capacity and the vessel was agitated at various agitator speeds, including but not limited to the scaled plant speed of $68 \mathrm{rpm}$ - different 
agitator speeds were necessary in order to determine the experimental minimum speed for complete particle suspension $\left(\mathrm{N}_{\mathrm{j} s}\right)$. After agitation was fully developed, after about 30 minutes, samples were withdrawn from the regular sampling location 1 inch from vessel floor. Five replicate samples were obtained for each agitator speed and volume level. The withdrawal velocity was maintained above the settling velocity of the heaviest particles. The weight of total solids (i.e. weight of sand, iron, and nickel) was determined by drying and weighing. The nickel content of the samples was determined by neutron activation analysis performed by the Analytical Development Section (ADS) of SRTC.

The standard test controls employed in this work were found to be adequate and met $\mathrm{QA}$ requirements. The transparent lab vessel was marked with a graduated scale to allow easy reading and adjustment of volume levels. The volume level readings were taken by more than one observer to minimize possible observer bias. The estimated errors in volume level readings were \pm 0.5 inches. A hand-held phototachometer was used to measure and control agitator rotational speeds. The phototachometer was calibrated using a fluorescent light bulb which gave a reading of 7200 rps.

Simulated Solids (Surrogate) in Slurry: There is no completely reliable substitute for using actual process slurry containing solids that are typically seen in canyon vessel. In the absence of process slurry, however, a simulated solids with average density and particle sizes similar to solids found in process vessels can obviate correction factors for property differences upon scale-up. Portions of the samples obtained from the process vessels were analyzed by inductively coupled plasma/mass spectrometry (ICP/MS) after complete dissolution of the samples in 8M nitric acid. After filtration, the ICP/MS analysis of the solution filtrate was used to determine the concentration of metal ions in samples. The undissolved solid residues remaining on filter paper were analyzed by scanning electron microscope (SEM). The scans and pictures were used to determine the particle size range of solids found in the samples. 
The samples obtained from Tank 18.3 over an eight month period were analyzed in SRTC and the data were recorded as shown in Tables 2 through 5. The metal ions identified in the samples from Tank 18.3 were divided into three major groups: Group I consisted of oxides of $\mathrm{Si}$ (sand), $\mathrm{Na}, \mathrm{Al}, \mathrm{Ca}, \mathrm{B}$, and $\mathrm{P}$. The average density and particle size of this group were $2.6 \mathrm{~g} / \mathrm{cm}^{3}$ and $243 \mu \mathrm{m}$, respectively. Group II solids were comprised of oxides of $\mathrm{Fe}, \mathrm{Cr}, \mathrm{Cu}, \mathrm{Mn}, \mathrm{Zr}$, and $\mathrm{Zn}$ (corrosion products) with an average density of about $5 \mathrm{~g} / \mathrm{cm}^{3}$ and a mean particle size of $93 \mu \mathrm{m}$. Group III solids consisted of the oxides of $\mathrm{Ni}, \mathrm{Mo}$, and $\mathrm{PuO} 2$ with an average density $10.7 \mathrm{~g} / \mathrm{cm}^{3}$ and mean particle size of about $13 \mu \mathrm{m}$. The mean concentration of total solids in slurry was limited to $1 \%$ by weight in the lab tests. The simulated solids slurry was made of $0.6 \%$ sand, $0.3 \%$ iron powder, and $0.1 \%$ by weight of nickel powder. The physical properties of the simulated solids slurry are shown in Table 2.

\section{RESULTS AND DISCUSSION}

The minimum agitator speed $\left(\mathrm{N}_{\mathrm{j} s}\right)$ for off-bottom suspension was predicted from Zweitering correlation using the dimensions of the model equipment, property of solids slurry, and different weight percent ratios of solids in slurry. The Zweitering equation was given as

$$
N_{j s}=\frac{S v^{0.1} d_{p}^{0.15}\left(\frac{g \Delta \rho}{\rho_{L}}\right)^{0.45} \bar{\phi}_{1}^{0.13}}{D^{0.85}}
$$

where $S$ is a dimensional constant, $v$ is the kinematic viscosity, $d_{p}$ is the suspended particle diameter, $g$ is the gravitational acceleration constant, $\Delta \rho$ is the density difference between

the solid particles and liquid phase, $D$ is the impeller diameter, $\rho_{\mathrm{L}}$ is the density of liquid phase, and $\bar{\phi}$ is mean solids concentration. The agitator speeds $\left(\mathrm{N}_{\mathrm{j} s}\right)$ predicted to suspend solid particles in lab model and plant equipment are shown in Table 6 (columns 5 and 6 , respectively). The minimum agitator speed for suspension of solid particles in canyon 
vessels was calculated from a scale-up relationship developed by Chapman ${ }^{3}$ for agitated vessels without coil helices. The scale up relationship was given as

$$
\frac{N_{j s-2}}{N_{j s-1}}=\left(\frac{\bar{\phi}_{2}\left(1-\bar{\phi}_{1}\right)}{\bar{\phi}_{1}\left(1-\bar{\phi}_{2}\right)}\right)^{0.12}\left(\frac{d_{p 2}}{d_{p 1}}\right)^{0.15}\left(\frac{\Delta \rho_{2}}{\Delta \rho_{1}}\right)^{0.4}\left(\frac{D_{1}}{D_{2}}\right)^{0.8}
$$

The subscripts 1 and 2 refer to the model and the plant equipments, respectively. Since the simulated solids slurry has the same physical properties as that of solids in a plant-size vessel, we use $\bar{\phi}_{1}=\bar{\phi}_{2}, d_{p 1}=d_{p 2}$, and $\Delta \rho_{1}=\Delta \rho_{2}$, in which case equation (2) reduces to a simple equal power per unit volume relationship on two scales of operation. Equation (2) becomes

$$
\frac{N_{j s-2}}{N_{j s-1}}=\left(\frac{D_{1}}{D_{2}}\right)^{0.8}
$$

The data in Table 6 show the minimum agitator speed for complete off the bottom suspension of solid particles as a function of the weight percentage of nickel particles in the simulated solids slurry. It can be seen that a plant agitator speed of about $77 \mathrm{rpm}$ is capable of providing complete off the bottom suspension of solids slurry containing of up to $0.05 \%$ of simulated plutonium bearing solid particles. A 10 -fold increase of the amount of nickel or simulated Pu bearing solid particles in the simulated solids slurry (i.e. from 0.05 to $0.5 \mathrm{wt} . \%$ ) would increase the plant agitator speed by $37 \%$, thus requiring an agitator speed of $106 \mathrm{rpm}$ to achieve complete off the bottom suspension. Since $\mathrm{Pu}$ bearing solids are not expected to exceed $0.05 \mathrm{wt} . \%$ of total solids in canyon vessels, the current plant agitator speed is sufficient for complete off the bottom solid suspension.

Confirmation of the correlation results was made by conducting experiments at agitator speeds of $280,370,528$, and $686 \mathrm{rpm}$. The agitator speed in the plant (68 rpm) corresponds to a lab agitator speed of $280 \mathrm{rpm}$. Plutonium bearing solid particles in 
canyon vessels were simulated by the nickel content in the surrogate material, which consists of $0.6 \%$ sand, $0.3 \%$ iron, and $0.1 \%$ by weight nickel. The nickel content in samples taken from agitated vessel was determined by neutron activation analysis. The analytical results were used to determine the degree of suspension of nickel in the tank. The average, standard deviation, lower $95 \%$ confidence limit, and upper $95 \%$ confidence limit for the degree of suspension of nickel was determined from a set of 5 replicate samples shown in Table 7. Figure 1 shows the degree of suspension of nickel as a function of agitator speed for $30 \%, 50 \%$, and $70 \%$ volume levels. As shown in Figure 1, all the agitator speeds $280,370,528$, and $686 \mathrm{rpm}$ achieved nearly complete uniformity of nickel particles in the vessel. It should be noted that the degree of suspension of solid particles decreases with increasing volume levels, as expected.

Figure 2 shows the degree of suspension of nickel, sand, and total solids as a function of agitator speed. The vessel was filled up to $70 \%$ volume capacity and charged with simulated solids slurry containing up to $0.5 \%$ by weight of nickel in sea sand; the mean solids concentration was $1 \%$ by weight. The weight percentage of solids in samples taken from agitated vessel was determined by drying and weighing and the weight percent of nickel was determined by neutron activation analysis. It can be seen in Figure 2 that the degree of suspension of nickel and sand/total was more than $95 \%$, thus indicating nearly complete uniformity of solids in the agitated vessel. Figure 3 shows the-degree of suspension of surrogate material containing $0.05 \%$ of nickel as a function of different volume levels. It may be noted that the degree of suspension of solid particles decreases with increasing volume levels and agitator speed. The results indicate that the solid particles were suspended off the bottom, but complete uniformity was not achieved throughout the vessel. It can be seen that as the agitator speed was increased more solids were suspended off the bottom and then dispersed into the upper section of the vessel. As a result, the concentration of solid particles at the sampling location (i.e. near the vessel floor) decreased with increasing agitator speed. 
Solid particle concentration uniformity in the axial direction (i.e. with vertical sampling height above the vessel floor) was examined using simulated solids slurry containing $0.25 \%$ nickel and $0.75 \%$ sand; the mean concentration of solids in the slurry was $1 \%$ by weight. The vertical sampling heights were $1^{\prime \prime}, 3^{\prime \prime}, 6^{\prime \prime}$, and $9^{\prime \prime}$ above the vessel floor. At each sampling height, 5 (replicate) samples were taken and analyzed for nickel content by neutron activation analysis. The uncertainty associated with the analytical method of neutron activation analysis for each sample was determined at the 1 sigma level. The average values from each set of 5 samples were calculated to be 1.31, 1.38, 1.28, and $1.43 \%$ at $1 ", 3^{\prime \prime}, 6^{\prime \prime}$, and $9^{\prime \prime}$ above the vessel floor, respectively. The degree of suspension of nickel was calculated in the same manner as previously described and, the results were analyzed statistically to determine the $95 \%$ confidence intervals. The average, standard deviation, lower $95 \%$ confidence limit (LCL), and upper 95\% confidence limit (UCL) are given in Table 8. The data reveal no apparent difference in degree of suspension in the axial direction.

\section{REFERENCES}

1. "Mixing Quality Characterization in Separations Process Tanks Part II: SolidLiquid Suspension (U) ", WSRC-TR-95-0258. Westinghouse Savannah River Company, Aiken, SC (July 1995).

2. T. N. Zwietering, "Suspending of Solid Particles in Liquid by Agitators", Chem. Eng. Sci., 8, 244 (1958)

3. C. M. Chapman, A. W. Nienow, M. Cooke, and J. C. Middleton, "ParticleGas-Liquid Mixing in Stirred Vessels. Part I: Particle-Liquid Mixing", Chem. Eng. Res. \& Des., 61(2), 71 (1983). 
Table I. Dimensions of Lab Model and Plant Equipment Vessels.

\begin{tabular}{|ccc|}
\hline & Model (Lab) equipment & Plant equipment \\
Tank, diameter (inches) & 18 & 96 \\
Impellers & 4.5 & 24 \\
diameter, inches & 1 & 5 \\
width, inches & 0.125 & 0.75 \\
thickness, inches & & 3.375 \\
Shaft $\quad 0.625$ & 226 \\
diameter, inches & 42 & 7 \\
length, inches & & \\
Baffles $\quad$ width, inches & 1.25 & 6 \\
Clearance (Off the bottom), & 1 & \\
& & \\
Coils (1/2 inch SS tubing) & 8 & 60 \\
Inner diameter, inches & 10.6 & 75 \\
Middle diameter, inches & 13.3 & \\
Outer diameter, inches & & \\
\hline
\end{tabular}


Chemical Process technology Department

Chemical \& Hydrogen Technology Section
WSRC-TR-96-0148

Revision 0

Table 2. Physical Properties of Simulated Solids Slurry

\begin{tabular}{|c|c|c|c|c|c|}
\hline \multicolumn{2}{|c|}{ Sea sand } & \multicolumn{2}{|c|}{ Iron powder } & \multicolumn{2}{|c|}{ Nickel powder } \\
\hline size $(\mu \mathrm{m})$ & vol. \% & $\underline{\text { size }}(\mu \mathrm{m})$ & vol. \% & $\underline{\text { size }}(\mu \mathrm{m})$ & vol. \% \\
\hline$>704.00$ & 2.69 & $>248.90$ & 8.81 & $>62.23$ & 3.53 \\
\hline 497.80 & 12.32 & 176.00 & 20.33 & 44.00 & 8.36 \\
\hline 352.00 & 32.09 & 124.45 & 24.07 & 31.11 & 13.59 \\
\hline 248.90 & 35.40 & 88.00 & 19.09 & 22.00 & 16.66 \\
\hline 176.00 & 13.59 & 62.23 & 12.59 & 15.56 & 14.74 \\
\hline 124.45 & 2.17 & 44.00 & 7.44 & 11.00 & 12.67 \\
\hline 88.00 & 1.33 & 31.11 & 3.89 & 7.78 & 10.61 \\
\hline \multirow[t]{5}{*}{$<62.23$} & 0.43 & 22.00 & 2.17 & 5.50 & 7.92 \\
\hline & & 15.56 & 1.30 & 3.89 & 6.93 \\
\hline & & $<11.00$ & 0.32 & 2.75 & 4.16 \\
\hline & & & & 1.94 & 0.71 \\
\hline & & & & $<1.38$ & 0.13 \\
\hline $\begin{array}{l}\text { Average particle } \\
\text { diameter }(\mathrm{m})\end{array}$ & $243 \times 10^{-3}$ & \multicolumn{2}{|r|}{$93 \times 10^{-3}$} & \multicolumn{2}{|c|}{$13 \times 10^{-3}$} \\
\hline $\begin{array}{l}\text { Average particle } \\
\text { density }\left(\mathrm{kg} / \mathrm{m}^{3}\right)\end{array}$ & 2650 & \multicolumn{2}{|r|}{5210} & \multicolumn{2}{|c|}{8980} \\
\hline \multicolumn{6}{|l|}{ Settling velocity, } \\
\hline $\begin{array}{r}\mathrm{U}_{\mathrm{t}}(\mathrm{m} / \mathrm{sec}) \\
(\mathrm{f} / \mathrm{min})\end{array}$ & $\begin{array}{l}0.0306 \\
(6.03)\end{array}$ & \multicolumn{2}{|r|}{$\begin{array}{l}0.0196 \\
(3.89)\end{array}$} & \multicolumn{2}{|c|}{$\begin{array}{c}8 \times 10^{-4} \\
(0.16)\end{array}$} \\
\hline
\end{tabular}


Chemical Process technology Department

Chemical \& Hydrogen Technology Section
WSRC-TR-96-0148

Revision 0

Table 3. Metal Ion Concentrations $(\mu \mathrm{g} / \mathrm{l})$ in Tank 18.3.

\begin{tabular}{|c|c|c|c|c|c|c|c|c|}
\hline $\begin{array}{l}\text { month } \\
\text { ions }\end{array}$ & January & February & March & April & June & July & August & October \\
\hline $\mathrm{Fe}$ & 24 & 8 & 30.6 & 1530 & 8 & 303 & 179 & 3040 \\
\hline $\mathrm{Si}$ & 701 & 527 & 227 & 232 & 1310 & 1320 & 212 & 56 \\
\hline $\mathrm{Cu}$ & 1 & 0 & 0 & 0 & 0 & 0 & 0 & 11 \\
\hline $\mathrm{Zn}$ & 0 & 0 & 0 & 0 & 1 & 2 & 23 & 0 \\
\hline $\mathrm{Na}$ & 127 & 159 & 141 & 127 & 239 & 283 & 66 & 65 \\
\hline $\mathrm{Ni}$ & 6 & 18 & 6 & 221 & 1 & 43 & 12 & 469 \\
\hline B & 75 & 60 & 3 & 45 & 149 & 153 & 41 & 44 \\
\hline $\mathrm{Ca}$ & 24 & 57 & 72 & 47 & 45 & 21 & 694 & 0 \\
\hline $\mathrm{Cr}$ & 3 & 0 & 7 & 431 & 0 & 78 & 1 & 831 \\
\hline $\mathrm{Al}$ & 59 & 47 & 21 & 24 & 119 & 148 & 2510 & 42 \\
\hline $\mathbf{P}$ & 0 & 0 & 0 & 0 & 0 & 0 & 45 & 13 \\
\hline $\mathrm{Pb}$ & 0 & 0 & 0 & 0 & 0 & 0 & 0 & 0 \\
\hline $\mathrm{Ba}$ & 11 & 9 & 6 & 0 & 216 & 0 & 0 & 0 \\
\hline Mn & 0 & 0 & 0 & 31 & 0 & 6 & 2 & 57 \\
\hline Mo & 0 & 0 & 0 & 0 & 0 & 1 & 7 & 12 \\
\hline Sn & 0 & 0 & 0 & 0 & 0 & 4 & 11 & 20 \\
\hline $\mathrm{Zr}$ & 6 & 3 & 18 & 291 & 6 & 281 & 0 & 1100 \\
\hline Total & 1037 & 888 & 559 & 2980 & 2094 & 2643 & 3803 & 5700 \\
\hline vol., ml & 0.01 & 0.037 & 0.028 & 0.026 & 0.030 & 0.021 & 0.017 & 0.018 \\
\hline
\end{tabular}


Table 4. Weight of Oxides (mg) of Metal Ions in Tank 18.3.

\begin{tabular}{|c|c|c|c|c|c|c|c|c|}
\hline $\begin{array}{l}\text { month } \\
\text { oxides }\end{array}$ & January & February & March & April & June & July & August & October \\
\hline $\mathrm{Fe}_{2} \mathrm{O}_{3}$ & 0.69 & 0.85 & 2.45 & 113.75 & 0.69 & 18.19 & 8.70 & 156 \\
\hline $\mathrm{SiO}_{2}$ & 15.00 & 41.72 & 13.60 & 12.90 & 84.1 & 59.30 & 7.71 & 2.16 \\
\hline $\mathrm{CuO}$ & 0.00 & 0.00 & 0.00 & 0.00 & 0.00 & 0.00 & 0.00 & 0.00 \\
\hline $\mathrm{ZnO}$ & 0.00 & 0.00 & 0.00 & 0.00 & 0.04 & 0.05 & 0.49 & 0.00 \\
\hline $\mathrm{Na} 2 \mathrm{O}$ & 3.42 & 15.86 & 10.64 & 8.90 & 19.33 & 16.02 & 3.02 & 3.15 \\
\hline $\mathrm{NiO}$ & 0.08 & 0.85 & 0.21 & 7.31 & 0.04 & 1.15 & 0.26 & 10.74 \\
\hline $\mathrm{B}_{2} \mathrm{O}_{3}$ & 4.83 & 14.30 & 5.41 & 7.54 & 28.79 & 20.69 & 4.49 & 5.10 \\
\hline $\mathrm{CaO}$ & 0.34 & 2.95 & 2.82 & 1.71 & 1.89 & 0.62 & 16.51 & 0.00 \\
\hline $\mathrm{Cr}_{2} \mathrm{O}_{3}$ & 0.09 & 0.00 & 0.57 & 32.76 & 0.00 & 4.79 & 0.05 & 43.72 \\
\hline $\mathrm{Al}_{2} \mathrm{O}_{3}$ & 2.23 & 6.57 & 2.22 & 2.36 & 13.49 & 11.75 & 161 & 2.86 \\
\hline $\mathrm{P}_{2} \mathrm{O}_{5}$ & 0.00 & 0.00 & 0.00 & 0.00 & 0.00 & 0.00 & 2.72 & 0.83 \\
\hline $\mathrm{PbO}$ & 0.00 & 0.00 & 0.00 & 0.00 & 0.00 & 0.00 & 0.00 & 0.00 \\
\hline $\mathrm{BaO}$ & 0.12 & 0.37 & 0.19 & 0.00 & 7.23 & 0.00 & 0.00 & 0.00 \\
\hline $\mathrm{MnO}_{2}$ & 0.00 & 0.00 & 0.00 & 1.28 & 0.00 & 0.20 & 0.05 & 1.62 \\
\hline $\mathrm{MoO}_{2}$ & 0.00 & 0.00 & 0.00 & 0.00 & 0.00 & 0.03 & 0.16 & 0.29 \\
\hline $\mathrm{SnO}$ & 0.00 & 0.00 & 0.00 & 0.00 & 0.00 & 0.10 & 0.21 & 0.41 \\
\hline $\mathrm{ZrO}_{2}$ & 0.08 & 0.15 & 0.68 & 10.22 & 0.24 & 7.97 & 0.00 & 26.75 \\
\hline Total & 27 & 84 & 39 & 199 & 156 & 141 & 205.62 & 254 \\
\hline
\end{tabular}


Chemical Process technology Department

Chemical \& Hydrogen Technology Section
WSRC-TR-96-0148

Revision 0

Table 5. Weight Percent Oxides of Metal Ions in Tank 18.3.

\begin{tabular}{|c|c|c|c|c|c|c|c|c|}
\hline $\begin{array}{c}\text { month } \\
\text { Oxides }\end{array}$ & January & February & March & April & June & July & August & October \\
\hline $\mathrm{B}_{2} \mathrm{O}_{3}$ & 18.02 & 17.05 & 13.88 & 3.77 & 19.19 & 10.86 & 2.19 & 0.76 \\
\hline $\mathrm{SiO}_{2}$ & 55.86 & 49.88 & 35.04 & 6.48 & 56.39 & 26.77 & 3.78 & 0.97 \\
\hline $\mathrm{Na}_{2} \mathrm{O}$ & 12.74 & 18.92 & 27.45 & 4.48 & 12.92 & 38.71 & 1.49 & 1.06 \\
\hline $\mathrm{P}_{2} \mathrm{O}_{5}$ & 0.00 & 0.00 & 0.00 & 0.00 & 0.00 & 0.00 & 0.4 & 0.22 \\
\hline $\mathrm{CaO}$ & 1.11 & 3.53 & 7.29 & 0.85 & 1.27 & 0.32 & 8.09 & 0.00 \\
\hline $\mathrm{Al}_{2} \mathrm{O}_{3}$ & 8.28 & 7.87 & 5.76 & 1.19 & 9.04 & 6.19 & 79.17 & 0.73 \\
\hline $\mathrm{MnO}_{2}$ & 0.00 & 0.00 & 0.00 & 0.65 & 0.00 & 0.11 & 0.02 & 0.98 \\
\hline $\mathrm{Fe}_{2} \mathrm{O}_{3}$ & 2.56 & 1.01 & 6.31 & 57.28 & 0.44 & 9.68 & 4.25 & 52.64 \\
\hline $\mathrm{Cr}_{2} \mathrm{O}_{3}$ & 0.35 & 0.10 & 1.49 & 16.44 & 0.05 & 2.53 & 0.03 & 14.41 \\
\hline $\mathrm{ZrO}_{2}$ & 0.29 & 0.17 & 1.79 & 5.13 & 0.16 & 4.2 & 0.00 & 19.30 \\
\hline $\mathrm{ZnO}_{2}$ & 0.00 & 0.00 & 0.00 & 0.00 & 0.02 & 0.02 & 0.24 & 0.00 \\
\hline $\mathrm{BaO}$ & 0.44 & 0.46 & 0.44 & 0.00 & 0.48 & 0.00 & 0.00 & 0.00 \\
\hline $\mathrm{CuO}$ & 0.06 & 0.00 & 0.00 & 0.00 & 0.00 & 0.00 & 0.00 & 0.20 \\
\hline $\mathrm{SnO}$ & 0.00 & 0.00 & 0.00 & 0.00 & 0.00 & 0.05 & 0.11 & 0.34 \\
\hline $\mathrm{PuO}_{2}$ & 0.28 & 0.99 & 0.53 & 3.68 & 0.03 & 0.6 & 0.13 & 8.12 \\
\hline $\mathrm{Total}_{2}$ & 100 & 100 & 100 & 100 & 100 & 100 & 100 & 100 \\
\hline
\end{tabular}


Chemical Process technology Department Chemical \& Hydrogen Technology Section
WSRC-TR-96-0148

Revision 0

Table 6. Minimum Agitator Speed $\left(\mathrm{N}_{\mathrm{js}}\right)$ Predicted from Zweitering Correlation

\begin{tabular}{|c|c|c|c|c|c|}
\hline $\begin{array}{c}\text { Weight \% } \\
\text { ratio } \\
(\mathrm{Si}: \mathrm{Fe}: \mathrm{Ni})\end{array}$ & $\begin{array}{l}\text { Avg. density } \\
\text { of slurry } \\
\left(\mathrm{kg} / \mathrm{m}^{3}\right)\end{array}$ & $\begin{array}{c}\text { Avg. particle } \\
\text { size }(\mathrm{m})\end{array}$ & $\begin{array}{c}\mathrm{N}_{\mathrm{js} s}, \text { model } \\
(\mathrm{rps})\end{array}$ & $\begin{array}{c}\mathrm{N}_{\mathrm{js}}, \text { model } \\
(\mathrm{rpm})\end{array}$ & $\begin{array}{c}\mathrm{N}_{\mathrm{j} s}, \text { Plant } \\
(\mathrm{rpm})\end{array}$ \\
$0.0 .0: 0.0$ & 2650 & $243 \times 10^{-3}$ & 4.71 & 282.8 & 74.1 \\
$0.98: 0: 0.02$ & 2777 & $238 \times 10^{-3}$ & 4.87 & 292.4 & 76.6 \\
$0.95: 0: 0.05$ & 2967 & $231 \times 10^{-3}$ & 5.07 & 304.3 & 76.7 \\
$0.9: 0: 0.1$ & 3283 & $220 \times 10^{-3}$ & 5.37 & 322.1 & 79.7 \\
$0.75: 0: 0.25$ & 4233 & $186 \times 10^{-3}$ & 6.07 & 364.1 & 84.4 \\
$0.5: 0: 0.5$ & 5815 & $128 \times 10^{-3}$ & 6.74 & 404.4 & 106 \\
$0.6: 0.3: 0.1$ & 3777 & $190 \times 10^{-3}$ & 5.69 & 341.6 & 89.5 \\
\hline
\end{tabular}


Chemical Process technology Department

Chemical \& Hydrogen Technology Section
WSRC-TR-96-0148

Revision 0

Table 7. Degree of Suspension of Nickel Particles in Model Vessel.

\begin{tabular}{|c|c|c|c|c|c|c|c|c|c|c|c|c|}
\hline Agitation & \multicolumn{3}{|c|}{$283 \mathrm{rpm}$} & \multicolumn{3}{|c|}{$370 \mathrm{rpm}$} & \multicolumn{3}{|c|}{$528 \mathrm{rpm}$} & \multicolumn{3}{|c|}{$686 \mathrm{rpm}$} \\
\hline$-(\%$ vol. $)$ & $30 \%$ & $50 \%$ & $70 \%$ & $30 \%$ & $50 \%$ & $70 \%$ & $30 \%$ & $50 \%$ & $70 \%$ & $30 \%$ & $50 \%$ & $70 \%$ \\
\hline 1 & & & & & & & & & & & & \\
\hline 1 & 114 & 107 & & 111 & 118 & & 121 & 110 & & 109 & III & 107 \\
\hline 2 & 118 & 103 & 108 & 120 & 110 & 129 & 121 & 110 & 100 & 117 & 138 & 90 \\
\hline 3 & 117 & 114 & 93 & 112 & 104 & 108 & 117 & 102 & 107 & 132 & 107 & 99 \\
\hline 4 & 89 & 102 & 111 & 122 & 102 & 94 & 129 & 105 & 88 & 111 & 113 & 103 \\
\hline 5 & 107 & 95 & 88 & 102 & 106 & 85 & 88 & 107 & 85 & 89 & 98 & 94 \\
\hline Average & 109 & 104 & 99 & 113 & 108 & 102 & 115 & 107 & 94 & 112 & 113 & 99 \\
\hline Std. Dev. & 11.9 & 7.1 & 10 & 8.0 & 6.0 & 17.1 & 15.8 & 3.4 & 9.2 & 15.7 & 14.9 & 6.9 \\
\hline LCL & 94 & 96 & 87 & 104 & 100 & 81 & 96 & 103 & 83 & 92 & 95 & 90 \\
\hline UCL & 124 & 96 & 111 & 123 & 116 & 123 & 135 & 111 & 105 & 131 & 132 & 107 \\
\hline
\end{tabular}

Simulated solids: $0.1 \% \mathrm{Ni}, 0.3 \% \mathrm{Fe}$, and $0.6 \%$ sand by weight

LCL $=$ Lower @ 95\% confidence limit

UCL= Upper @ 95\% confidence limit 
Chemical Process technology Department

Chemical \& Hydrogen Technology Section
WSRC-TR-96-0148

Revision 0

Table 8. Degree of Suspension of Nickel Particles at Vertical Sampling Heights.

\begin{tabular}{|cc|c|c|c|}
\hline Sample \# & 1" Off-bottom & 3" Off - bottom & 6" Off - bottom & 9" Off- bottom \\
\cline { 2 - 5 } & 98.6 & 90.7 & 95.9 & 98 \\
2 & 93.4 & 94.37 & 99.5 & 96.5 \\
3 & 94.8 & 96.6 & 91.2 & 94.7 \\
4 & 94.9 & 98.4 & 97.5 & 95.9 \\
5 & 93.4 & 93.1 & 96.6 & 115.4 \\
Average & 95.1 & 94.6 & 96.1 & 100.1 \\
Std. deviation & 2.1 & 3.0 & 3.1 & 8.7 \\
LCL & 92.5 & 90.9 & 92.3 & 89.4 \\
UCL & 97.7 & 98.4 & 100 & 111 \\
\hline
\end{tabular}

LCL $=$ lower $95 \%$ confidence limit $\mathrm{UCL}=$ Upper $95 \%$ confidence limit

Fill capacity $=70 \%(\mathrm{v} / \mathrm{v})$

Simulated solids slurry:

$$
\begin{aligned}
& \text { nickel }=0.1 \%(\mathrm{w}) \\
& \text { iron }=0.3 \%(\mathrm{w}) \\
& \text { sand }=0.6 \%(\mathrm{w}) \\
& \text { total }=1.0 \%(\mathrm{w})
\end{aligned}
$$




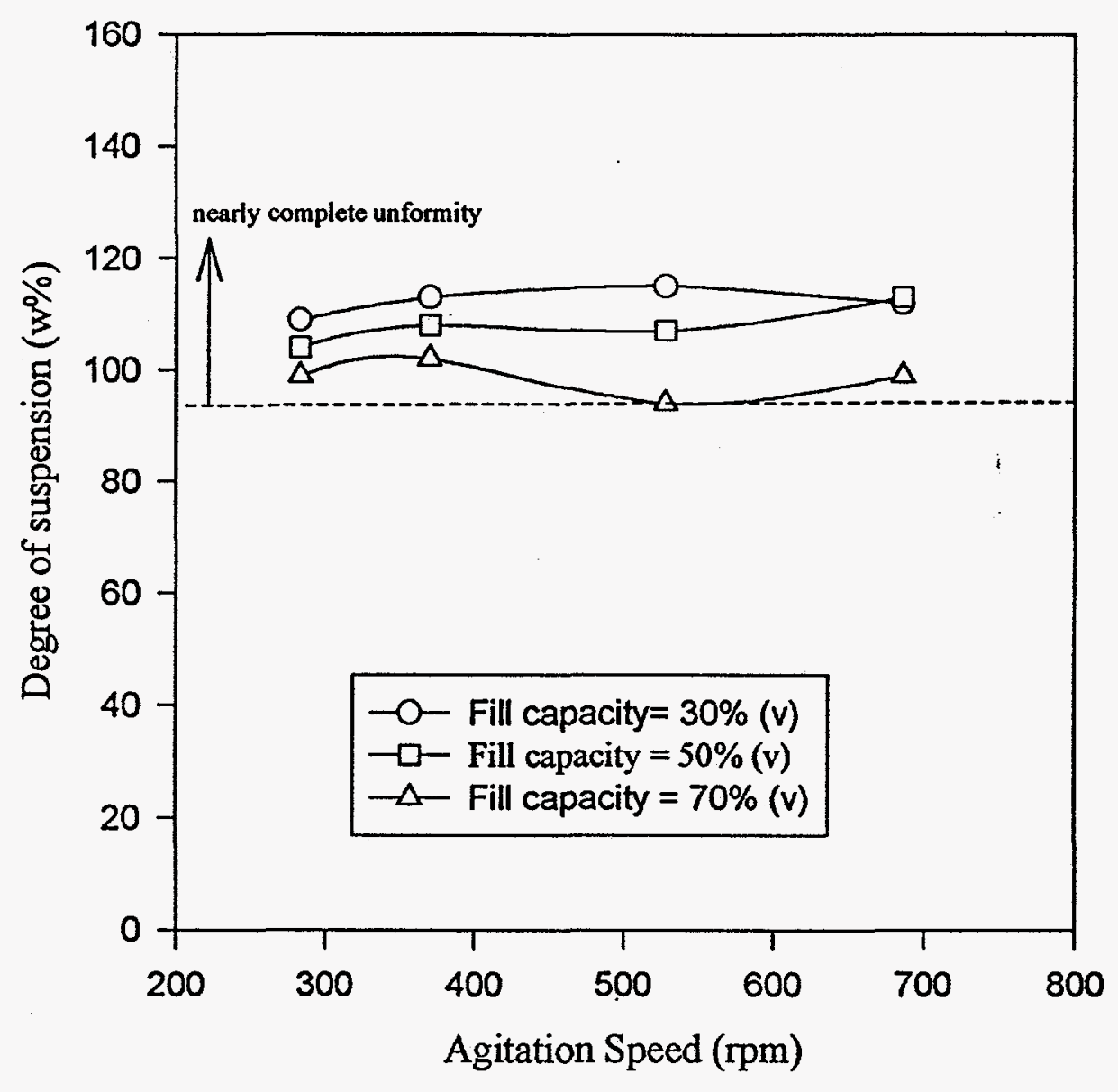

Figure 1. The degree of suspension of nickel in agitated small vessel. 


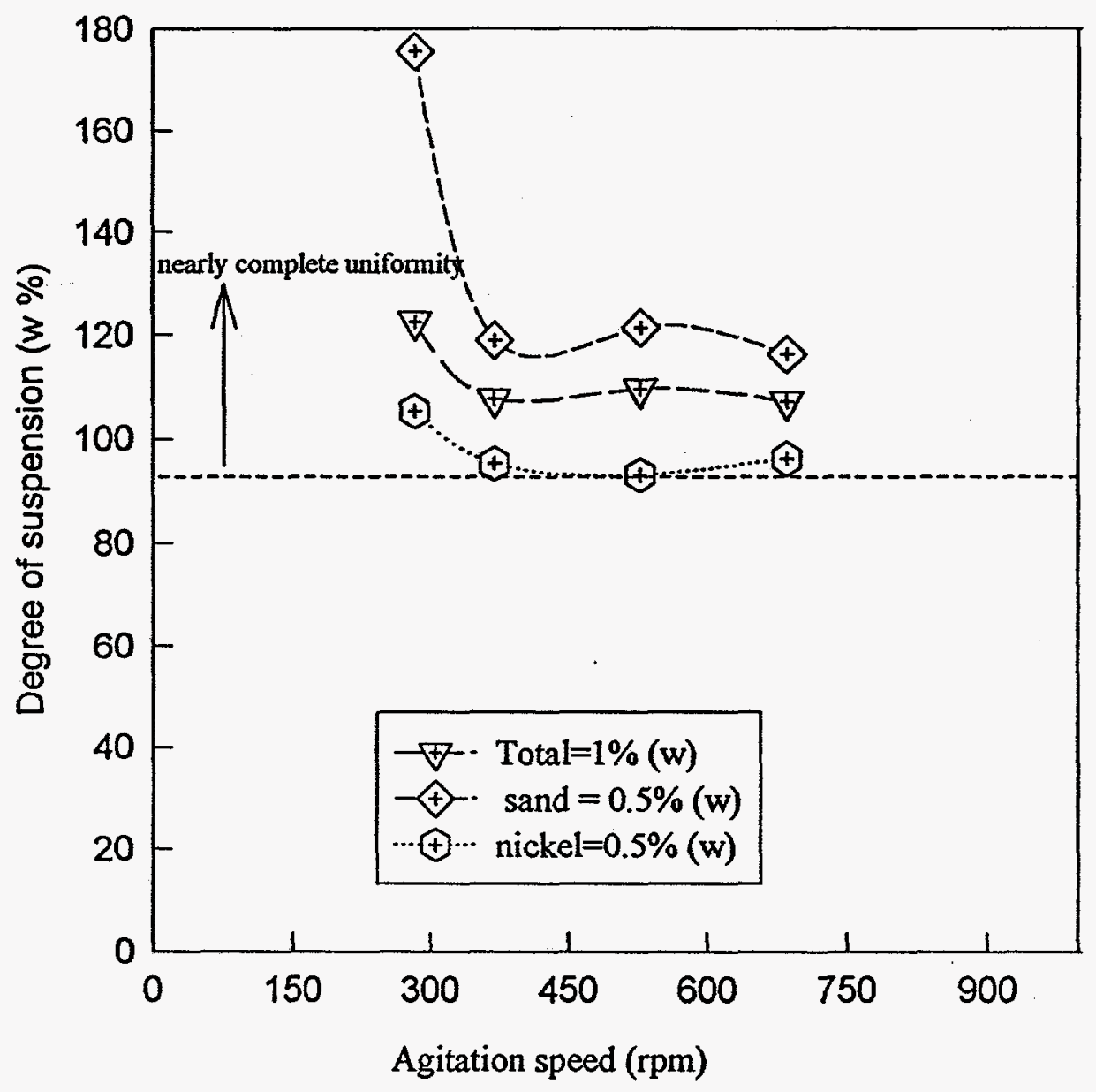

Figure 2. The degree of suspension of solid particles as a function of agitation speed.. 


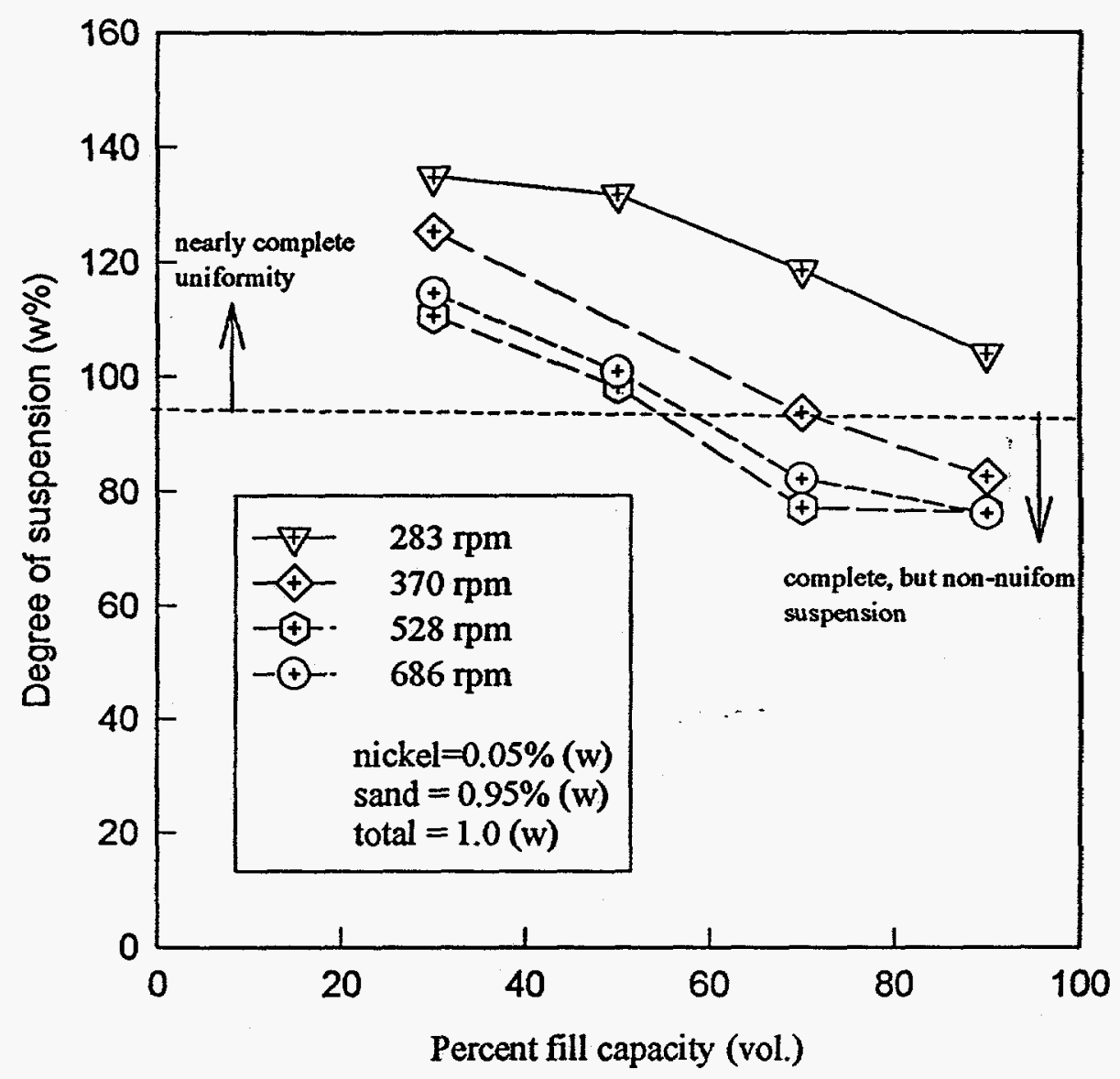

Figure 3 .The degree of suspension of solid particles as a function of tank fill capacity. 
Chemical Process technology Department WSRC-TR-96-0148 Chemical \& Hydrogen Technology Section

\section{WSRC DISTRIBUTION}

G. J . Winkler, 221-H

R. H. Spires, 221-F

B. A. Clinton, 221-H

A. P. Mock, 703-F

R. M. Mobley, 703-F

C. E. Pickett, 221-H

C. R. Wolfe, 773-A

D. L. Bleile, 704-30F

E. A. Kyser, 773-A

F. R. Graham, 773-A

J. R. Knight, 773-A

J. S. Evans, 703-F

T. A. Reily, 707-F

T. C. Robinson, 221-F

S. J. Brown, 221-14F

D. A. Burge, 773-A

STI, 703-43A. 